\title{
The Tango Between Art. I7(3) Brussels Ibis and Art.6(4)(b) Rome I under the Beat of Package Travel Directive
}

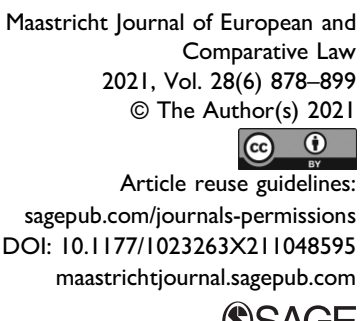

@SAGE

\section{Zhen Chen (D)*}

\begin{abstract}
Package travel tourists are explicitly protected as consumers under Article 6(4)(b) Rome I, but not under Article 17(3) Brussels lbis since it does not even mention the term 'package travel'. Such discrepancy is widened with the replacement of Directive 90/3/4 by Directive 2015/2302 with enlarged notion of package travel. As regards protecting package travel tourists as consumers with favorable jurisdiction and applicable law rules, this article argues that Article 17(3) Brussels Ibis is two steps behind Article 6(4)(b) Rome I. In order to close the gap, a uniform concept of package travel should be given. To this end, it is suggested that Article 17(3) Brussels lbis should adopt the notion of package travel employed in Article 6(4)(b) Rome I. Despite this, these two provisions only cover packages containing transport, as an exception of transport contracts. Packages not including transport do not fall under the exception of transport contracts. Since all package travel contracts should be protected as consumer contracts, regardless of containing transport or not, it is more logical to delete the exception of transport contracts and create a separate provision to protect package travel contracts as consumer contracts.
\end{abstract}

\section{Keywords}

International civil litigation, conflicts of laws, transport/carriage contract, consumer contract, package travel tourist, package travel directive, weaker party protection, linked travel agreements, harmonization, consumer protection

\footnotetext{
*Ulrik Huber Institute for Private International Law, University of Groningen, Groningen, the Netherlands

Corresponding author:

Zhen Chen, Ulrik Huber Institute for Private International Law, University of Groningen, Poststraat II, 97I2 ER,

Groningen, the Netherlands.

Email: zhen.chen@rug.nl
} 


\section{Introduction}

It takes two to tango, one as a leader and another one as a follower. In order to present a beautiful tango, the leader and the follower need to take consistent and harmonious moves under the beat of background music. In the field of European private international law, Brussels Ibis Regulation ${ }^{1}$ and Rome I Regulation ${ }^{2}$ are dancing partners that work closely with different roles. When it comes to consumer protection in international litigation, Brussels Ibis Regulation is the leader and Rome I Regulation is the follower, since the determination of competent courts precedes the determination of applicable law. The protection of consumer contracts in European private international law was first introduced by the 1968 Brussels Convention in its Articles 13-15 with beneficial jurisdiction rules and then followed by Article 5 of the 1980 Rome Convention, the predecessor of Article 6 Rome I Regulation, on consumer applicable law rules with a broader scope of consumer contracts. Currently, a consumer is entitled to sue the business, or to be sued by the business, in the courts of the country of the consumer's domicile (consumer forum) ${ }^{3}$ and protected by the law of the consumer's country of habitual residence. ${ }^{4}$ These favorable rules are based on the idea that consumers, as the weaker contracting party, are in need of special protection under private international law. ${ }^{5}$

Three conditions have to be met for the application of consumer private international law rules: (i) there is a consumer, a professional and a concluded consumer contract; (ii) the business pursues commercial or professional activities in the consumer's country or directs such activities to that country; (iii) the contract falls with the scope of such activities. ${ }^{6}$ Moreover, not all kinds of consumer contracts are protected, for instance, transport contracts are excluded from the scope. ${ }^{7}$ Nevertheless, transport contracts which are part of a package travel contract, as an exception, are protected as consumer contracts. Article 17(3) Brussels Ibis Regulation prescribes that Section 4 on consumer contracts 'shall not apply to a contract of transport other than a contract which, for an inclusive price, provides for a combination of travel and accommodation'. Likewise, Article 6(4)(b) Rome I Regulation stipulates that choice-of-law rules over consumer contracts 'shall not apply to a contract of carriage other than a contract relating to package travel within the meaning of Council Directive 90/314 ${ }^{8}$ of 13 June 1990 on package travel, package holidays and

1. Regulation (EU) No 1215/2012 of the European Parliament and of the Council of 12 December 2012 on jurisdiction and the recognition and enforcement of judgments in civil and commercial matters, also known as the Brussels Ia Regulation, Brussels Recast Regulation, or Brussels I Regulation Recast. It repealed Regulation (EC) 44/2001(Brussel I Regulation), the successor of Brussels Convention.

2. Regulation (EC) No 593/2008 of the European Parliament and of the Council of 17 June 2008 on the law applicable to contractual obligations (Rome I Regulation).

3. Article 18(1) and Article 18(2) of Brussels Ibis Regulation.

4. Article 6(1) of Rome I Regulation.

5. Recital 18 of Brussels Ibis Regulation and Recitals 23-24 of Rome I Regulation.

6. Article 17(1) of Brussels Ibis Regulation and Article 6(1) of Rome I Regulation. Cases regarding the requirement of three conditions, see Case C-774/19 A. B. and B. B. v. Personal Exchange International, EU:C:2020:1015; Case C-498/16 Schrems v. Facebook Ireland, EU:C:2018:37; Case C-419/11 Česká Spořitelna, a.s. v. Gerald Feichter, EU: C:2013:165; Case C-218/12 Lokman Emrek v. Vlado Sabranovic, EU:C:2013:666; Case C-89/91 Shearson Lehmann Hutton, Inc. v. TVB, [1993] ECR I-139; Case C-96/00 Gabriel v. Schlank \& Schick GmbH, [2002] ECR I-6367; Case C-27/02 Engler v. Janus Versand GmbH, [2005] ECR I-481; Case C-269/95 Francesco Benincasa v. Dentalkit Srl, [1997] ECR I-3767; Case C-464/01 Johann Gruber v. BayWa AG, [2005] ECR I-439.

7. Article 17(3) of Brussels Ibis Regulation and Article 6(4)(b) of Rome I Regulation.

8. Council Directive 90/314/EEC of 13 June 1990 on package travel, package holidays and package tours (1990 Package Travel Directive). 
package tours'. The difference is that Article 17(3) Brussels Ibis does not explicitly mention the term 'package travel'.

In fact, the phrase 'contracts which, for an inclusive price, provide for a combination of travel and accommodation' was first used in Article 5(5) Rome Convention, which was followed by the Brussels I Regulation and remains unchanged in the Brussels Ibis Regulation. Thus, although the Brussels Regime is the leader who takes the first step by establishing protective consumer jurisdiction rules and the Rome Regime follows, the Rome Regime is the leader who first protects package travel contracts as consumer contracts and the Brussels Regime follows. Since a consistent and harmonious interpretation is required regarding the same concept provided in these two Regulations across the EU, it is questionable whether the phrase used in Article 17(3) Brussels Ibis should be interpreted as having exactly the same meaning of package travel enshrined in Article 6(4)(b) Rome I.

Moreover, the material scope of Article 6(4)(b) Rome I is broader because of the replacement of Directive $90 / 314$ by Directive $2015 / 2302 .{ }^{9}$ With the harmonization realized by the 2015 Package Travel Directive, the question 'Which court is competent?' might be even more important than the question 'Which law is applicable?' for package travel contracts. The main reason is that Article 29 of the 2015 Package Travel Directive explicitly states that, as of 1 July 2018, references to the repealed 1990 Directive shall be construed as references to this Directive. Such a reading is not possible with regard to Brussels Ibis, as Article 17(3) Brussels Ibis does not refer to Directive 90/314.

Since Article 17(3) Brussels Ibis does not explicitly state that 'a contract which, for an inclusive price, provides for a combination of travel and accommodation' equates with a 'package travel contract', whether the notion 'package travel' in Directive 2015/2302 can be referred to interpret Article 17(3) Brussels Ibis remains questionable. Such ambiguity might create one loophole that can be easily utilized by a business by claiming, for instance, that a contract with a combination of transport and other travel services is not a package travel contract, but a transport contract. As a result, a consumer in such a contract who could have been protected as a package travel tourist with favorable consumer jurisdiction rules will lose jurisdiction benefits granted by Articles 18-19 Brussels Ibis. This is the case in Peter Pammer v. Reedere Karl Schluter, ${ }^{10}$ in which the German company claimed that the 'voyage by freighter' in question was not a cruise tour or a package travel, but a transport contract, whereas the Austrian consumer claimed that the 'voyage by freighter' constituted a package travel under Article 15(3) Brussels I (predecessor of Article 17(3) Brussels Ibis). The difference is that consumers in a transport contract cannot invoke the protective jurisdiction rules, ${ }^{11}$

9. Directive (EU) 2015/2302 of the European Parliament and of the Council of 25 November 2015 on package travel and linked travel arrangements (2015 Package Travel Directive).

10. Case C-585/08 Peter Pammer v. Reedere Karl Schluter GmbH \& Co KG, EU:C:2010:740.

11. For transport contracts, transport companies generally incorporate a jurisdiction clause in their pre-drafted standardized contracts that grants exclusive jurisdiction of the courts of the country where the company is domiciled. Such forum selection clause was not subject to an individual negotiation and has the object or effect of excluding or hindering the consumer's right to take legal action. The CJEU has repeatedly held that such clause is to be regarded as unfair, under Article 3(1) of Directive 93/13 on unfair terms in consumer contracts, if it causes a significant imbalance in the parties' rights and obligations arising under that contract. Although the incorporated jurisdiction clause in a transport contract is considered as unfair, it does not mean consumer jurisdiction rules in Articles 17-19 Brussels Ibis Regulation shall apply to determine the competent court. Pursuant to Article 7(1)(b) Brussels Ibis Regulation, the court of the place of performance of the obligation shall have jurisdiction. Both the place of departure and that of arrival must be considered, as the principal places of provision of the services which are the subject of a transport contract and those places are 
whereas consumers in a package travel contract are entitled to invoke such protective rules. Therefore, the interpretation of the phrase utilized in Article 17(3) Brussels Ibis was essential to determine the scope of package travel contracts covered by Articles 18-19 Brussels Ibis.

\section{Article I5(3) of Brussels I Regulation and Directive 90/3 I4}

In Pammer, Article 15(3) Brussels I interacted with Article 6(4)(b) Rome I under Directive 90/314. The question arises whether the CJEU's reasoning in Pammer regarding Brussels I (enacted before Rome I) can be transposed to Brussels Ibis (enacted after Rome I). Since Article 15(3) Brussels I was the predecessor of Article 17(3) Brussels Ibis, for the purpose of 'continuity' and consistent interpretation of the same concept required under Recital 34 Brussels Ibis, the CJEU's reasoning in Pammer is equally applicable to Article 17(3) Brussels Ibis. The Pammer case highlights a phenomenon increasingly experienced by consumers who are injured while enjoying holidays overseas and would like to bring proceedings in the courts of their home state, while such holiday is a not a regulated package within the meaning of the Package Travel Directive. ${ }^{12}$

\section{A. 'Voyage by freighter' or 'package travel'}

The question raised in Pammer was whether a 'voyage by freighter' can be considered as 'a contract which, for an inclusive price, provides for a combination of travel and accommodation' under Article 15(3) Brussels I. ${ }^{13}$ Mr Pammer, domiciled in Austria, made a booking with a German company via the website of its intermediary company for a voyage by freighter from Trieste to Far East at an overall price. ${ }^{14}$ The vessel which operated the voyage was an industrial freight ship. This Austrian resident sued the Germany company for a refund before an Austrian court because the facts were inconsistent with the description on the intermediary company's website. The German company objected the international and territorial jurisdiction of the Austrian court, claiming the 'voyage by freighter' was not a cruise tour nor a package travel. ${ }^{15}$

The Austrian district court held that it had jurisdiction because the voyage by freighter was a consumer contract, namely a package travel contract, and the intermediary had conducted advertising activities in Austria via its website on behalf of the defendant. ${ }^{16}$ The appellate court declared that Austrian courts lacked jurisdiction because the voyage contract constituted a contract of transport and the fact that the proposed voyage, namely a lengthy crossing from Europe to the Far East, involved a degree of comfort did not transform the voyage contract into a consumer contract. ${ }^{17}$ The Supreme Court of Justice deemed that it was unclear to what extent the voyage by freighter was

agreed in that contract. See Case C-519/19 Ryanair DAC v DelayFix, EU:C:2020:933, para. 57; C-240/98 to C-244/98 Océano Grupo Editorial and Salvat Editores, EU:C:2000:346, para. 22, 24; C-243/08 Pannon GSM, EU:C:2009:350, para. 40, 41; C-137/08 VB Pénzügyi Lízing, EU:C:2010:659, para. 53, 54; C-204/08 Rehder, EU:C:2009:439, para. 47; C-606/19 flightright, EU:C:2020:101, para. 26.

12. C. Lane, Jurisdiction, consumer protection, cruising by freighter and a moonlight flit (from an Austrian hotel), www. lexology.com/library/detail.aspx?g=87ffe401-8dc5-4e99-8bdc-db0f362abbbc.

13. Opinion of Advocate General in Case C-585/08 Pammer, EU:C:2010:273, para. 1.

14. Ibid., para. 9.

15. Ibid.

16. Ibid., para. 12; Case C-585/08 Pammer, para. 19.

17. Case C-585/08 Pammer, para. 20. 
comparable to a cruise, which is overwhelmingly regarded as a 'package' ${ }^{18}$ Regarding the criteria to be applied for categorizing a contract as a package travel contract, the Austrian Supreme Court expressed its doubts. ${ }^{19}$ The question referred to the CJEU was: 'Does a "voyage by freighter" constitute package travel for the purposes of Article 15(3) of Regulation No 44/2001?,20

\section{B. Transport contract}

Advocate General Trstenjak rephrased the referred question as two sub-questions: first, whether a contract for a voyage by freighter, which comprised not only travel but also accommodation, falls within the concept of 'a contract which, for an inclusive price, provides for a combination of travel and accommodation' enshrined in Article 15(3) Brussels I, and second, how such a concept is to be interpreted, ${ }^{21}$ or whether this concept should be interpreted in precisely the same way as the term 'package' in Article 2(1) Directive 90/314. ${ }^{22}$

Based on a literal and teleological interpretation, the Advocate General held that the first question must be answered in the affirmative. ${ }^{23}$ First, Mr Pammer booked a voyage by freighter which comprised both travel and accommodation with an inclusive price paid for the package. ${ }^{24}$ A literal interpretation of Article 15(3) Brussels I would indicate that a contract concerning the organization of a voyage by freighter at issue constitutes 'a contract which, for an inclusive price, provides for a combination of travel and accommodation'. ${ }^{25}$ Second, the purpose of Brussels I Regulation is to exclude the contracts of which the main purpose is transportation from the scope of protective consumer jurisdiction regime. ${ }^{26} \mathrm{Mr}$ Pammer did not conclude the contract merely in order to be transported from Trieste to the Far East, but, as an observer or a tourist, to experience events onboard the freighter and see the places where the freighter docked. ${ }^{27}$ The organizer of such a trip was responsible for both the standard of transportation and the quality of accommodation. Hence, a teleological interpretation of Article 15(3) Brussels I would reach the same conclusion as that of a literal interpretation. $^{28}$

\section{Notion of 'a contract which, for an inclusive price, provides for a combination of travel and accommodation'}

As to the second sub-question, the Advocate General also gave an affirmative answer. First, it should consider the travaux préparatoires of Brussels I Regulation and the broader context of EU legislation using the same term: 'a contract which, for an inclusive price, provides for a combination of travel and accommodation'. ${ }^{29}$ Second, the explanatory memorandum accompanying the

\footnotetext{
18. Opinion of Advocate General in Case C-585/08 Pammer, para. 13.

19. Ibid.

20. Ibid., para. 14 .

21. Ibid., para. 38 .

22. Ibid., para. 45 .

23. Ibid., para. 41 .

24. Ibid., para. 42 .

25. Ibid.

26. Ibid., para. 43 .

27. Ibid.

28. Ibid.

29. Ibid., para. 45 .
} 
proposal for Brussels I Regulation ${ }^{30}$ expressly termed contracts covering both travel and accommodation for an all-in price as package holiday contracts and also referred to the 'package' definition in Directive 90/314. ${ }^{31}$ The explanatory memorandum indicates that the notion 'a contract which, for an inclusive price, provides for a combination of travel and accommodation' is to be interpreted in exactly the same way as the term 'package' in Directive 90/314. ${ }^{32}$ Third, Rome Convention, or Rome I Regulation, is of relevance for the construction of Article 15(3) Brussels I Regulation, as Article 5(5) Rome Convention provides the same expression 'contracts which, for an inclusive price, provide for a combination of travel and accommodation'. ${ }^{33}$

The fact that Brussels I Regulation later adopts the same terminology as Rome Convention indicates that the EU legislature intended to give a uniform interpretation of the term prescribed in both provisions. ${ }^{34}$ Furthermore, the substantive scope and the provisions of Rome I Regulation should be consistent with Brussels I Regulation, ${ }^{35}$ Thereby, the concept of carriage contract, provided in Article 6(4)(b) Rome I and Article 15(3) Brussels I, that falls outside or within the scope of consumer contracts must be uniformly interpreted. ${ }^{36}$ The Advocate General concluded that the concept 'a contract which, for an inclusive price, provides for a combination of travel and accommodation' prescribed in Article 15(3) Brussels I has to be interpreted in exactly the same way as the term 'package' enshrined in Article 2(1) Directive 90/314. ${ }^{37}$

\section{A uniform interpretation or an identical interpretation?}

The CJEU also gave an affirmative answer to the main question. ${ }^{38}$ Nevertheless, the CJEU's reasoning only partly followed the opinion of the Advocate General. The referred question was rephrased by the CJEU as whether a contract concerning a voyage by freighter is a transport contract envisaged by Article 15(3) Brussels I. ${ }^{39}$ This question was also divided into two sub-questions: first, whether the concept of 'package travel' specified in Directive 90/314 is of relevance in interpreting Article 15(3) Brussels Ii, ${ }^{40}$ second, whether a voyage by freighter such as that at issue corresponds to the concept 'package' in Directive 90/314. ${ }^{41}$

As regards the first sub-question, the CJEU pointed out that although Brussels I Regulation postdates Directive 90/314, the term 'package' does not appear in Article 15(3) Brussels I. ${ }^{42}$ Instead, the

30. COM (1999) 348 final, Proposal for a Council Regulation (EC) on jurisdiction and the recognition and enforcement of judgment in civil and commercial matters, p. 16.

31. Opinion of Advocate General in Case C-585/08 Pammer, para. 46.

32. Ibid.

33. Ibid., para. 47.

34. Ibid.

35. Recital 7 of Rome I Regulation. The rules determining the applicable of a contract were intended, as much as possible, to be consistent with jurisdiction rules stipulated in the Brussels I Regulation. The same goes for a cross-border contract relating to touristic services concluded over the Internet. R. Steennot, Booking Your Holiday Online: Which Law Applies?, https://biblio.ugent.be/publication/5749826/file/5749863.pdf, p. 1, 2.

36. Opinion of Advocate General in Case C-585/08 Pammer, para. 48.

37. Ibid., para. 49. The same conclusion was made by Nielsen, P.A., in U. Magnus and P. Mankowski (ed.), Brussels I Regulation (Sellier, Munich, 2007), p. 318.

38. Case C-585/08 Pammer, para. 46.

39. Ibid., para. 34.

40. Ibid., para. 38

41. Ibid., para. 44.

42. Ibid., para. 39. 
term used by the EU legislature for the purposes of Brussels I Regulation is identical to that in the Rome Convention, which was replaced by Rome I Regulation, of which Article 6(4)(b) explicitly refers to the concept of 'package travel' in Directive 90/314. ${ }^{43}$ The fact that the transport/carriage contract is provided in Article 15(3) Brussels I and Article 6(4)(b) Rome I shows that the EU legislature intended to cover the same types of contracts which will be governed under the protective consumer jurisdiction and choice-of-law rules. ${ }^{44}$ Moreover, the CJEU also referred to Recital 7 Rome I Regulation ${ }^{45}$ and its explanatory memorandum, ${ }^{46}$ but reached a conclusion different from that of the Advocate General. That is, it is appropriate to interpret Article 15(3) Brussels I in line with Article 6(4)(b) Rome I which refers to the concept of 'package travel' laid down in Directive $90 / 314 .^{47}$

As to the second sub-question, the CJEU also gave an affirmative answer. ${ }^{48}$ Specifically, the CJEU pointed out that for a service to be qualified as a package within the meaning of Article 2(1) Directive 90/314, it is enough if, first, it combines tourist services sold at an inclusive price including two of the three services, namely transport, accommodation and other tourist services not ancillary to transport or accommodation and accounting for a significant proportion of the package; ${ }^{49}$ and second, it covers a period of more than 24 hours or includes overnight accommodation. ${ }^{50}$ The CJEU analysed that since the voyage by freighter at issue involved not only transport but also accommodation for an inclusive price for a period of over 24 hours, such a service fulfills the necessary conditions for a 'package' set out in Article 2(1) Directive 90/314 and thus falls within the definition laid down in Article 15(3) Brussels I. ${ }^{51}$

Unlike the opinion of the Advocate General, although the same conclusion was made as regards whether the voyage in freight is a package travel or not, the CJEU held that the term in Article 15(3) Brussels I should be interpreted in line with Article 6(4)(b) Rome I by reference to Directive 90/ 314 , instead of being construed as the same meaning. Such interpretation is of significance to understand the interaction of Article 17(3) Brussels Ibis and Article 6(4)(b) Article Rome I under the Directive 2015/2302.

\section{Article 17(3) Brussels ibis regulation and directive 20I5/2302}

Article 17(3) Brussels Ibis utilizes the same expression provided in Article 15(3) Brussels I. This means the term used in Article 5(5) Rome Convention, which has been abandoned by its successor Article 6(4)(b) Rome I, is still used in Article 17(3) Brussels Ibis. Meanwhile, Directive 2015/2302, which repealed Directive 90/314, has adopted a broader definition of 'package' in its Article 3(2). As to the question how the concept of 'transport contract' enshrined in Article 17(3) Brussels Ibis

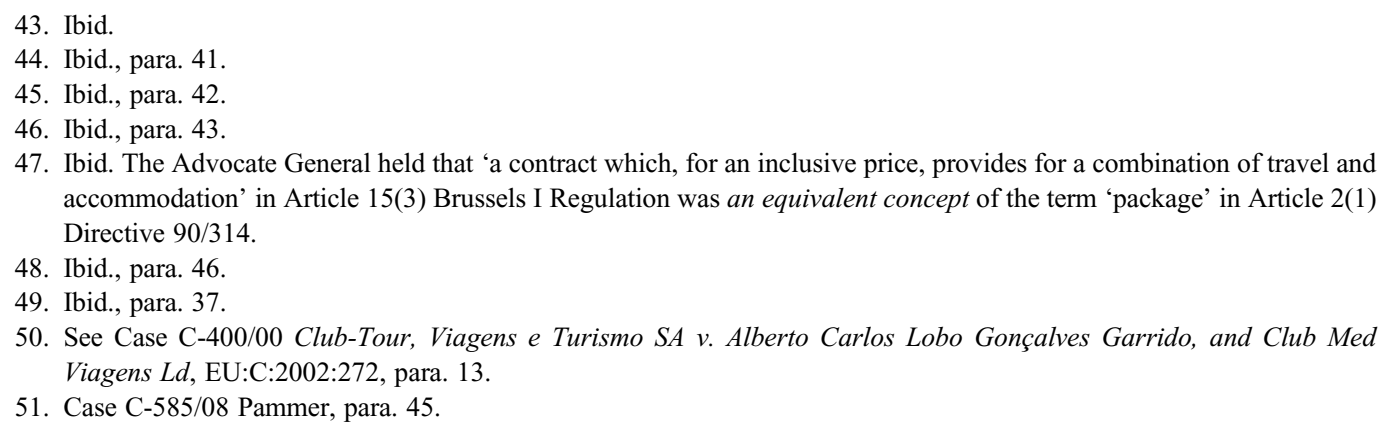


should be interpreted and whether the term 'a contract of transport other than a contract which, for an inclusive price, provides for a combination of travel and accommodation' has the same meaning as the 'package travel contract' provided in Article 3(3) Directive 2015/2302, the answer can be found in the CJEU's Pammer judgment.

The Pammer judgment would suggest that Article 17(3) Brussels Ibis should be construed in line with Article 6(4)(b) Rome I which refers to the concept of 'package travel' laid down in Directive 2015/2302. ${ }^{52}$ The Advocate General, however, would argue that Article 17(3) Brussels Ibis should be interpreted in exactly the same way as the term 'package' enshrined in Article 3(2) Directive 2015/2302. ${ }^{53}$ Such interpretation is less convincing, based on the analysis in Pammer case, for several reasons.

First, from a perspective of literal interpretation, clearly, the terms used in Article 15(3) Brussels I and Article 2(1) Directive 90/314 are totally different. In the absence of an explicit reference to Directive 90/314 and specific mention of the term 'package' in Article 15(3) Brussels I, there is no direct link between these two provisions. The link is only created through a corresponding provision in Article 6(4)(b) Rome I which expressly refers to the package definition. ${ }^{54}$ Such accessory connection, depending on the existence and interpretation of another legal document, is indirect and weak. Second, from a perspective of historical construction, although the explanatory memorandum accompanying Brussels I Regulation referred to the 'package' definition in Directive 90/314, ${ }^{55}$ the EU legislature could also have directly referred to that directive and assumed its terminology in its final version. ${ }^{56}$ The fact that, in the final text of Article 15(3) Brussels I, the EU legislature did not make express reference to the package notion in Directive 90/314 indicates that the final term should not be interpreted in exactly the same way as the term 'package' in Directive 90/314.

Additionally, the self-contradictory construction by the Advocate General in Point 45 and Note 16 also supports this argument. Specifically, the Advocate General analysed that, pursuant to Article 2(1) Directive 90/314, a 'package' is involved if the contract combines at least two of the three following services: transport, accommodation and non-ancillary services. A package is a combination of (i) transport and accommodation; (ii) accommodation and other tourist services; (iii) transport and other tourist services; (iv) all three types of services. The first type, a combination of 'transport and accommodation', is already included in Article 15(3) Brussels I. The second type, a combination of 'accommodation and other tourist services', does not necessarily fall within the scope of Article 15(3) Brussels I, as the term 'other tourist services' is not specified in Article 15(3). Whether the wording 'travel' in Article 15(3) should be interpreted as exactly the same meaning as 'other tourist services' remains disputed. The same goes for the third type with a combination of 'transport and other tourist services' and the fourth type with a combination of all three kinds of services. In short, the types of package travel covered in Article 15(3) Brussels I are limited to 'transport+' combination, whereas the types of a package included in Article 2(1) Directive 90/314 are much broader. As the CJEU stated, the concept of 'transport+' packages covered in Article 15(3) Brussels I is "close to ${ }^{, 57}$ those corresponding packages in Directive 90/314. The

52. Ibid.

53. Opinion of Advocate General in Case C-585/08 Pammer, para. 49.

54. Ibid., para. 21.

55. COM (1999) 348 final, p. 16; Opinion of Advocate General in Case C-585/08 Pammer, para. 21, 46.

56. Opinion of Advocate General in Case C-585/08 Pammer, para. 22.

57. Case C-585/08 Pammer, para. 36. 
wording used here is 'close to', rather than 'identical', 'the same as' or 'equivalent', which indicates that the CJEU did not plan to interpret such two terms as having exactly the same meaning.

Thus, Directive 90/314 is relevant for the interpretation of Article 15(3) Brussels I, but it has a broader meaning of package travel than that in Brussels I. Accordingly, Article 17(3) Brussels Ibis is to be interpreted in the light of the corresponding provision in Rome I Regulation which refers to the concept of 'package travel' in Directive 2015/2302. Yet the latter has a broader meaning than the former.

\section{The notion of package travel under Directive 2015/2302}

The material scope of Article 6 Rome I Regulation is limited to 'contract relating to package travel' within the meaning of Directive 90/314, but this directive does not contain a definition of 'contract relating to package travel' other than a notion of 'package' which consists of at least two different kinds of services (transportation, accommodation and other services). ${ }^{58}$ The concept of package travel in Directive 90/314 was challenged by the fast-changing travel market, the increasingly usage of internet to offer or sell travel services and the emergence of more customized packages left in a legal 'grey zone'. ${ }^{59}$ Under this background, Directive 2015/2302 was adopted in order to broaden the scope of protection, to enhance transparency and to increase legal certainty for travellers and traders. ${ }^{60}$

The most important change of Directive 2015/2302 is the extended definition of 'package travel'. The packages travel covered by Article 17(3) Brussels Ibis and Article 6(4)(b) Rome I are confined to the combination of 'transport+' types. Yet it is possible that a package travel does not contain any transport component. ${ }^{61}$ Since packages containing transport fall outside the exception of transport contracts, the question then arises as regards how Brussels Ibis Regulation and Rome I Regulation should interact with Directive 2015/2302 and whether all kinds of packages (packages not including transport), or only certain types of packages (packages containing transport) should be protected as consumer contracts. For instance, it is not entirely clear whether packages contain services (other than transport) which are entirely carried out outside the consumer's country are excluded from the scope of protective regime by virtue of Article 6(4)(a) Rome I or included as a re-exception of transport contract under 6(4)(b) Rome I. ${ }^{62}$

\section{A. New types of packages}

In accordance with Directive 2015/2302, 'package' means 'a combination of at least two different types of travel services for the purpose of the same trip or holiday', ${ }^{63}$ and 'package travel contract' means 'a contract on the package as a whole or, if the package is provided under separate contracts,

58. M. Wilderspin, 'Article 6: Consumer Contracts in Rome I Regulation', in U. Magnus and P. Mankowski, Rome I Regulation (Sellier European Law Publishers, 2017), p. 469, para. 38.

59. Recital 2 of Directive 2015/2302.

60. Ibid. Tourists can easily book various travel services directly at the website of service providers like hotels and airlines, or through an intermediary's website, such as booking.com, airbnb.com and cheaptickets.com. Domestic tourists are more exposed to foreign service providers and vice versa, which makes it difficult to predict which court is competent and which law is applicable for both parties. R. Steennot, Booking Your Holiday Online: Which Law Applies?, https:// biblio.ugent.be/publication/5749826/file/5749863.pdf, p. 1.

61. M. Wilderspin, in U. Magnus and P. Mankowski, Rome I Regulation, p. 470, para. 38.

62. Ibid., para. 39 .

63. Article 3(2) of Directive 2015/2302. 
all contracts covering travel services included in the package'. ${ }^{64}$ In addition, if travel services are advertised or sold not under the term 'package' but under a similar term, such as 'combined deal', 'all-inclusive' or 'all-in arrangement', that indicates a close connection between the travel services concerned, a combination of such travel services should also be classified as a package. ${ }^{65}$ The term 'travel services' is defined in Article 3(1) Directive 2015/2302, according to which a 'package' could be a combination of (i) carriage of passengers and accommodation; (ii) carriage of passengers and rental of cars/other motor vehicles/motorcycles; (iii) carriage of passengers and any other tourist service; (iv) accommodation and rental of cars/other motor vehicles/motorcycles; (v) accommodation and any other tourist service; (vi) rental of cars/other motor vehicles/motorcycles and any other tourist service; and (vii) a combination of any three out of the (a)-(d) travel services. It is clear that the scope of package travel contract covered in Directive 2015/2302 is significantly expanded, and the categories of package travel contracts are much broader than that in Directive 90/314. Apart from the addition of the component of vehicle rental, the extension of Directive $2015 / 2302$ to 'linked travel arrangements' makes the identification of the material scope of Article 6(4)(b) Rome I and Article 17(3) Brussels Ibis more complex. ${ }^{66}$

A literal interpretation of Article 17(3) Brussels Ibis would be that contracts of transport, not providing for a combination of travel and accommodation for an inclusive price, would be excluded from the material scope of consumer jurisdiction rules. ${ }^{67}$ The transport contracts, not being protected as package travel contracts, or consumer contracts, will be subject to general jurisdiction or special jurisdiction rules enshrined in Article 4 and Article 7 Brussels Ibis Regulation respectively. Such jurisdiction rules are far from beneficial to consumers. ${ }^{68}$ Hence, it is crucial to determine which kinds of transport contracts are excluded from the material scope of Articles 17-19 Brussels Ibis Regulation. ${ }^{69}$ In this regard, it is of significance to figure out what exactly the terms 'transport contract', 'travel' and 'accommodation' in Article 17(3) Brussels Ibis Regulation refer to. Meanwhile, how the concept 'package travel' in Directive 2015/2302 is to be construed will directly determine the scope of carriage contracts included by the consumer conflicts rules under Article 6(4)(b) Rome I.

To answer the question of what constitutes a package travel under Brussels Ibis Regulation and Rome I Regulation, it is necessary to analyse the criteria applicable to determine the existence of a package travel under Directive 2015/2302. The classification of a package travel should be based on objective criteria, which predominantly relate to the way in which the travel services are presented or purchased, and this can also protect the travellers' reasonable expectation in accordance with Recital 10 of Directive 2015/2302.

\section{B. The criteria applicable to the classification of a 'package travel'}

The package travel is characterized by a combination of more than two different types of travel services for the purpose of the same trip or holiday. ${ }^{70}$ The single travel service is the basic element or

64. Article 3(3) of Directive 2015/2302.

65. Preamble 10 of the 2015 Package Travel Directive.

66. R. Plender and M. Wilderspin, The European Private International Law of Obligations (5th edition, Sweet \& Maxwell, 2020), p. 264, para. 9-032.

67. R. Steennot, 'Rules of Jurisdiction and Conflict Rules Relating to Online Cross-border Contracts Concerning Touristic Services Provided to Consumers', Computer Law \& Security Law (2016), p. 485.

68. Ibid.

69. Ibid.

70. Article 3(2) of Directive 2015/2302. 
component of a combined travel services in packages, and thus should be considered as a fundamental criterion to determine whether a contract can be classified as a package travel contract. If there are more than two types of 'travel services' set out in Article 3(1) Directive 2015/2302 combined for the purpose of the same trip or holiday, such a combination would constitute a package travel, provided that it covers a period of more than 24 hours or an overnight accommodation. ${ }^{71}$ Therefore, the criteria applicable to the classification of a 'package travel' can be found in the four types of single travel services specified in Article 3(1) Directive 2015/2302.

I. Carriage of passengers. The first type of a travel service under Article 3(1)(a) Directive 2015/2302 is a carriage of passengers. The carriage of passengers can be conducted in four modes of transport: air, rail, waterborne and road. ${ }^{72}$ The contract of carriage of passengers alone, as a single travel service, should not be considered as a package travel contract. General jurisdiction rules in Brussels Ibis Regulation (Article 7 and Article 4) and special applicable law rules on contracts of carriage in Rome I Regulation (Article 5) may apply. The Giuliano/Lagarde Report explained that the reason for the exclusion of carriage contracts was the special protective measures for consumer contracts are not appropriate for governing contracts of this type.

In accordance with Article 6(4)(b) Rome I, all types of contracts of carriage, irrespective of whether by air, by sea, by rail or by land, are excluded. ${ }^{73}$ A contract of transport which offers accommodation merely to increase the degree of comfort for passengers, such as night train or night bus, does not constitute a package travel contract and thus falls within the scope of exclusion of Article 6(4)(b) Rome I. ${ }^{74}$ Such accommodation service is secondary to transport services. However, certain types of contracts of carriage of passengers could be qualified as a package travel. For instance, the contract of carriage of passengers by sea could be a 'transport contract' for the provision of cruises. ${ }^{75}$ The term 'cruise' is defined by Article 3(t) Regulation $1177 / 2010$ as a transport service by sea or inland waterway, operated exclusively for the purpose of pleasure or recreation, supplemented by accommodation and other facilities, exceeding two overnight stays on board. The carriage of passengers in a cruise ship is to be classified as a package travel, provided that it lasts more than 24 hours or includes overnight accommodation. ${ }^{76}$ The same applies for extended full service trips on luxury trains, so-called rail cruises, such as the legendary 'Orient Express'. ${ }^{77}$ Such rail cruises and cruise ships, just like the voyage by freighter in Pammer case, in essence, is not merely for the purpose of transportation from Place A to Place B but also for the purpose of pleasure or recreation, supplemented by accommodation and other facilities. The voyage contract in Pammer included at least three of these elements and thus was necessarily analogous with package travel regulated

71. Article 2(2)(a) of Directive 2015/2302.

72. M.G. Sanches Lima, Traveller Vulnerability in the Context of Travel and Tourism Contracts (Springer Nature Switzerland AG, 2018), p. 115.

73. F. Ragno and J.A. Bischoff, 'The Law Applicable to Consumer Contracts under the Rome I Regulation', in F. Ferrari and S. Leible (eds.), Rome I Regulation (Sellier European Law Publishers, 2009), p. 220, para. 15.

74. R. Steennot, Booking Your Holiday Online: Which Law Applies?, https://biblio.ugent.be/publication/5749826/file/ 5749863.pdf, p. 3.

75. Article 3(m) of Regulation 1177/2010.

76. See M.G. Sanches Lima, Traveller Vulnerability in the Context of Travel and Tourism Contracts, p. 124.

77. O. Remien, 'Tourism, Conflict of Laws and the Rome I Regulation', in K.B. Woelki et al. (eds.), Convergence and Divergence in Private International Law (Eleven International Publishing, 2010), p. 500. 
under Directive 90/314. ${ }^{78}$ Thus, these kinds of carriage contracts should be protected as consumer contracts and included in Article 17(3) Brussels Ibis and Article 6(4)(b) Rome I.

If a boat which includes accommodation is charted for transportation, the question is whether this constitutes a contract of carriage or a package. ${ }^{79}$ Where a boat is chartered for holiday purposes, either at sea or on inland waterways, it is not the same as a pure contract of carriage, but more of the nature of a consumer contract, if not a package travel contract. ${ }^{80}$ Therefore, just like (rail) cruises, consumer jurisdiction and choice-of-law rules will apply. Nevertheless, if the service is to be supplied to the consumer exclusively in a country other than that of the consumer's habitual residence, Article 7(1)(b) Brussels Ibis and Article 4(1)(b) Rome I may still apply. ${ }^{81}$ Where a coach or an airplane is chartered for one specific trip, the main purpose clearly is for transportation, and in this case Article 7(1)(b) Brussels Ibis and Article 5(2) Rome I shall apply. ${ }^{82}$

Since it is possible for a package to fall within the scope of Directive 2015/2302 even if it contains no transport component, whether Article 6 Rome I only applies to packages at least one of the components is transport or to all kinds of packages? ${ }^{83}$ One possible interpretation is Article 6 Rome I only applies to packages which contains transport component, because such package is the exception of the excluded contract which itself only relates to contracts of carriage. ${ }^{84}$ Such narrow interpretation seems consistent with the wording in Article 17(3) Brussels Ibis which states 'this Section shall not apply to a contract of transport other than a contract which, for an inclusive price, provides for a combination of travel and accommodation'. A literal interpretation of the phrase in Article 17(3) Brussels Ibis would indicate that protective consumer jurisdiction rules do not apply to contracts offering a combination of hotel accommodation and other services not including transport, and by analogy it applies to its corresponding provision in Article 6(4)(b) Rome I. ${ }^{85}$ An opposing opinion is that Article 6(4)(b) Rome I Regulation applies to all kinds of packages. ${ }^{86}$ Comparing these two interpretations, it is more likely that the broad interpretation of packages corresponds to the EU legislature's intention, as the operators offering packages, whether contain transport or not, are in a different position than those receiving services. ${ }^{87} \mathrm{~A}$ strict interpretation would lead to a paradoxical result that while a package travel which contains transport component is protected as a consumer contract, a package travel not containing transport component is not protected as a consumer contract. Package travel contracts should be protected as consumer contracts as a whole, regardless of whether containing transport component or not. In this regard, Article 5(5) Rome Convention achieved such purpose by regulating package travel contract separately in parallel with its Article 5(4)(a), which expressly excludes contracts of carriage. Consequently, the legal framework in Article 5(5) Rome Convention could be transposed to Article 17 Brussels Ibis and Article 6 Rome I by removing packages from the exception of transport contracts and creating a new provision.

78. L. Gillies, 'Clarifying the Philosophy of Article 15 in the Brussels I Regulation', 60 International and Comparative Law Quarterly (2011), p. 562.

79. O. Remien, in K.B. Woelki et al. (eds.), Convergence and Divergence in Private International Law, p. 500.

80. Ibid.

81. Ibid.

82. Ibid.

83. R. Plender and M. Wilderspin, The European Private International Law of Obligations, p. 263, para. 9-031.

84. Ibid.

85. Ibid.

86. F. Ragno and J.A. Bischoff, in F. Ferrari and S. Leible, Rome I Regulation, p. 142.

87. R. Plender and M. Wilderspin, The European Private International Law of Obligations, p. 264, para. 9-031. 
2. Accommodation: Hotel contract, timeshare contract, renting a holiday apartment. The second type of travel service, pursuant to Article 3(1)(b) Directive 2015/2302, is 'accommodation which is not intrinsically part of carriage of passengers and is not for residential purposes'. The question is what does the phrase 'not intrinsically part of' mean? Firstly, if accommodation is provided as a compensation for providing other services, such as hotel accommodation in the case of flight cancellation, such service is 'intrinsically part of carriage of passengers'. A combination of transport and such kind of accommodation does not constitute a package travel. ${ }^{88}$ Secondly, if an accommodation contract includes other complementary services, such as pick-up service from the airport to the hotel, such a transport service is not independent but intrinsically part of hotel services and thus the combination of these two services is not a package travel. ${ }^{89}$

Accommodation for residential purposes, including for long-term language courses, should not be considered as accommodation. ${ }^{90}$ An accommodation contract for non-residential purposes usually includes facilities, ${ }^{91}$ and, by nature, is a service contract. ${ }^{92}$ The notion of 'service contract' should be interpreted autonomously and in line with Article 7(1)(b) Brussels Ibis Regulation. ${ }^{93}$ However, there is no specific time requirement, in particular upper limit, to distinguish between accommodation contract for residential purposes and for non-residential purposes. Even if the accommodation included in package travel is normally of relatively short duration, it cannot be regarded as a defining element of the term 'accommodation'. ${ }^{94}$ Since no maximum duration has been provided for, ${ }^{95}$ under Article 2(2)(a) Directive 2015/2302, any travel exceeding 24 hours or includes an overnight accommodation falls within the definition of packages. The question then arises as to whether a contract of accommodation for a period of over 6 months shall be regarded as a service contract or a tenancy of immovable property.

A contact concluded for the purposes of accommodation could be a hotel contract, a timeshare contract, a long-term holiday product contract, or an apartment-renting contract. The conclusion of a hotel contract is the most common way to get accommodation for individual tourists. ${ }^{96}$ A hotel contract should be regarded as a service contract, rather than a tenancy of immovable property, as a considerable number of services are provided under a hotel contract. ${ }^{97}$ A hotel contract, not constituting a package travel under Directive 2015/2302 should be subject to Article 7(1)(b) Brussels Ibis and Article 4(1)(b) Rome I. The reasoning behind Article 4(1)(b) Rome I Regulation is to protect service providers (mostly, but not limited to, those in the tourist industry) in a situation that is strongly connected to the country where the services are provided, in which the consumers cannot reasonably count on the application of the law of the consumer's country of habitual residence. ${ }^{98}$

88. R. Steennot, Computer Law \& Security Law (2016), p. 486.

89. Ibid.

90. Recital 17 of Directive 2015/2302.

91. Such as a clean bed, clean towers and sheets in the condition that the room and the hotel structure must maintain in a clean manner at least concerning certain standards not harmful to health. See M.G. Sanches Lima, Traveller Vulnerability in the Context of Travel and Tourism Contracts, p. 128.

92. Ibid.

93. F. Ragno and J.A. Bischoff, in F. Ferrari and S. Leible, Rome I Regulation, p. 147, para. 40.

94. Case C-237/97 AFS Intercultural Programs Finland ry, EU:C:1999:69, para. 27.

95. Ibid.

96. O. Remien, in K.B. Woelki et al. (eds.), Convergence and Divergence in Private International Law, p. 508.

97. Ibid.

98. Giuliano/Lagarde Report, O.J. 1980 No. C 282/1, 24; F. Ragno and J.A. Bischoff, in F. Ferrari and S. Leible, Rome I Regulation, p. 219, para. 14. 
Timeshare contracts, together with long-term holiday products, ${ }^{99}$ are regulated under Directive $2008 / 122 / \mathrm{EC},{ }^{100}$ and this refers to contracts of a duration of more than one year under which a consumer acquires the right to use one or more overnight accommodation for more than one period of occupation. ${ }^{101}$ According to Article 6(4)(c) Rome I Regulation, timeshare contracts, as an exception of contracts in relation to immovable property, fall within the scope of consumer conflicts rules. Timeshare tourists are protected by the consumer conflicts rules just like package travel tourists. ${ }^{102}$ However, it is unclear whether timeshare tourists are protected as package travel tourists under Brussels Ibis Regulation, since it does not expressly mention 'timeshare', except for a comparable concept of 'tenancies of immovable properties concluded for temporary private use for a maximum period of six consecutive months' stipulated in Article 24(1) on exclusive jurisdiction. In the absence of a specific provision that explicitly protects timeshare contracts as consumer contracts, it is hard to reach a conclusion that Articles 17-19 Brussels Ibis Regulation apply to timeshare contracts.

Renting a holiday apartment may create more procedural problems than timeshare contracts, in particular with regard to the question whether exclusive jurisdiction of forum rei sitae applies to the tenancy of holiday apartments. ${ }^{103}$ The CJEU gave an affirmative answer to this question in Rösler v. Rottwinkel. ${ }^{104}$ The Brussels I Regulation 'partly softened' ${ }^{105}$ it by introducing a specific rule for tenancy of immovable property up to six months together with one condition to confine its application. ${ }^{106}$ This provision remains unchanged in the Brussels Ibis Regulation, ${ }^{107}$ under which a tenancy of immovable property over six months will be subject to the exclusive jurisdiction of forum rei sitae. Such jurisdiction is doubtful as it does not distinguish the purpose of tenancy of immovable property. The same goes for Article 4(1)(d) Rome I Regulation, which does not distinguish between tenancy for holiday and for other purposes. This indicates that in the case of renting a holiday apartment, the general conflicts rule, instead of consumer conflicts rule, will apply. ${ }^{108}$ In this case, the applicable law is subject to the complete freedom of choice under Article 3 Rome I Regulation; in the absence of a choice, Article 4(1)(c) will apply and lead to the law of the country where the property is situated. ${ }^{109}$ In addition, it does not exclude a choice-of-law clause referring to a law other than that of the common habitual residence. ${ }^{110}$ This may lead to the evasion of the consumer protection available under the law of the common habitual residence. ${ }^{11}$ As a result, whereas the timeshare tourists can receive consumer protection under Rome I

99. Article 2(1)(b) of Directive 2008/122/EC.

100. Directive 2008/122/EC of the European Parliament and of the Council of 14 January 2009 on the protection of consumers in respect of certain aspects of timeshare, long-term holiday product, resale and exchange contracts, OJ L 33, 3.2.2009.

101. Article 2(1)(a) of Directive 2008/122/EC.

102. Ibid.

103. Ibid., p. 506.

104. Case C-241/83 Erich Rösler v Horst Rottwinkel, EU:C:1985:6.

105. O. Remien, in K.B. Woelki et al. (eds.), Convergence and Divergence in Private International Law, p. 506.

106. Article 22(1) of Brussels I Regulation.

107. Article 24(1) of Brussels Ibis Regulation.

108. O. Remien, in K.B. Woelki et al. (eds.), Convergence and Divergence in Private International Law, p. 506.

109. Ibid.

110. Ibid.

111. Ibid. 
Regulation, the tourists renting a holiday apartment are not protected under such favorable rules, which is doubtful. ${ }^{112}$

3. Rental of cars, other motor vehicles, or motorcycles. The third type of travel service, stipulated in Article 3(1)(c) Directive 2015/2302, is 'rental of cars, other motor vehicles within the meaning of Article 3(11) Directive 2007/46/EC, or motorcycles requiring a Category A driving license in accordance with Article 4(3)(c) Directive 2006/126/EC.' This vehicle rental is a new criterion or component added in Directive 2015/2302, in comparison with Directive 90/314.

(I) 'transport services' or 'contract of carriage'. Renting a car could be an alternative for tourists to move from place $\mathrm{A}$ to $\mathrm{B}$, or possibly to $\mathrm{C}$ and $\mathrm{D}$. The question is whether a car rental contract falls within the scope of carriage contract and thus be subject to conflicts rules provided in Article 5 Rome I Regulation. ${ }^{113}$ The CJEU held, in easyCar $v . O F T,{ }^{114}$ regarding the interpretation of Article 3(2) Directive 97/7/EC, ${ }^{115}$ that contracts for the provision of car hire services are included in 'contracts for the provision of transport services'. ${ }^{116}$ The term 'transport services' represents a sector and therefore relates generally to services in the transport sector. ${ }^{117}$ Despite this, the CJEU also emphasized that the term 'contracts of carriage' relates only to the carriage of passengers and goods performed by the carrier. Based on this, a car rental contract, which provides a means of transport on a driving-yourself basis, should not be classified as a contract of carriage. ${ }^{118}$

Moreover, the fact that the travel service of 'rental of cars, other motor vehicles or motorcycles' has been added as a single service, in parallel with 'carriage of passengers', in Article 3(1)(c) Directive 2015/2302, can also support this argument. If a car rental contract is construed as a contract of carriage of passengers, there is no need to establish two individual provisions regulating the same kind of travel services. As a result, a combination of 'flight+car rental' services should not be regarded as a combination of two types of transport services, but as a package travel with two types of tourist services. However, the term 'a contract of transport other than a contract which, for an inclusive price, provides for a combination of travel and accommodation' stipulated in Article 17(3) Brussels Ibis does not expressly include car rental. Therefore, the package travel covered by Article 17(3) Brussels Ibis is limited to 'transport+' combination and does not include a combination of packages with 'transport+car rental', 'car rental+', 'motor vehicle rental+', or 'motorcycles rental+' services. By contrast, 'transport+vehicle rental' packages are encompassed in Article 6(4)(b) Rome I because of the express reference to the 2015 Package Travel Directive. The closed circle with exhaustive examples in Article 17(3) Brussels Ibis increases discrepancy or inconsistency with Article 6(4)(b) Rome I, which has a non-exhaustive list open for broader interpretation.

(II) Service contract or contract for the lease of movables? Although a car rental contract is not a contract of carriage and thus Article 5 Rome I Regulation shall not apply, it is still disputed

112. Ibid.

113. Ibid., p. 502.

114. Case C-336/03 easyCar (UK) Ltd v. Office of Fair Trading, EU:C:2005:150.

115. Directive 97/7/EC of the European Parliament and of the Council of 20 May 1997 on the protection of consumers in respect of distance contracts(OJ L 144, 4.6.1997) repealed by Directive 2011/83/EU.

116. easyCar, para. 31 .

117. easyCar, para. 22 and 30.

118. O. Remien, in K.B. Woelki et al. (eds.), Convergence and Divergence in Private International Law, p. 503. 
whether a car rental contract should be classified as a service contract or as a contract for the lease of movables. The contract of car rental may be regarded as a service contract for several reasons. First, the consumer traveller in a car rental contract gets not solely a car, but a car that is fuelled, reconditioned and cleaned prior to the service. ${ }^{119}$ Second, car rental companies or agencies may offer sophisticated online services to the consumer traveller, such as tracking the car to ensure the parties to the contract are protected against risks. ${ }^{120}$ Third, the Consumer Rights Directive stresses that car rental is a service and consumers in a car rental service should benefit from the protection afforded by this directive. ${ }^{121}$ If a car rental contract is classified as a service contract, Article 7(1)(b) Brussels Ibis and Article 4(1)(b) Rome I will apply.

Nevertheless, a car rental contract may also be classified as a contract for the lease of movables. The main argument is that the car rental supplier offers only the car to be used as the object of the contract without additional services such as a driver. ${ }^{122} \mathrm{~A}$ car rental contract merely provides a means of transport and the car is leased out, as a movable property, without providing a driver. Such a car rental contract is based on self-driving and the car is used as a transportation tool for moving around, which is comparable to the rental of motor vehicles or motorcycles. If classified as a contract for the lease of movables, under Rome Convention, the lease of movables, including cars, are not protected by consumer conflicts rules enshrined in its Article 5. ${ }^{123}$ The Rome I Regulation, however, has expanded the scope of applying consumer conflicts rules to almost all kinds of contracts concluded by a consumer, to the extent that as long as there is no specific exception prescribed in its Article 6, protective consumer conflicts rule will apply. ${ }^{124}$ It is clear that Article 6(4)(c) Rome I excludes the lease of immovables from the scope of application of consumer conflicts rules, but there is no specific provision that excludes the lease of movables from the scope of consumer contracts. Therefore, if the prerequisites are fulfilled, the conflicts rule on consumer contracts shall apply to car rental contracts under Article 6(1) Rome I Regulation. ${ }^{125}$

(III) The international nature of car rental services. Although car rental contract might be protected as a consumer contract, Article 6(4)(a) Rome I may still apply to protect business parties and their legitimate expectation. The question is in which situation a car rental company should be regarded as providing services exclusively in a particular country. The regulation per se does not provide a clear clarification. Provided that a car rental company which provides the possibility of the lease of its cars in Country A and the return in Country B, C and D, it is clear that the services provided by this company are not limited to one country. ${ }^{126}$ If the place of lease and return as well as the use of rented cars are limited in Country A, the car rental service should be considered as exclusively domestic. The tricky part is, for instance, if a car rental company allows the lease and return of its cars only in Country A, but its cars can also be used in Country B, C and D, will such a crossborder element affect its nature of exclusively domestic?

There are two approaches available when answering this question. The first approach is through a strict interpretation. That is to say, as the services are not provided in the country of the

119. M.G. Sanches Lima, Traveller Vulnerability in the Context of Travel and Tourism Contracts, p. 127.

120. Ibid.

121. Ibid.

122. Ibid.

123. O. Remien, in K.B. Woelki et al. (eds.), Convergence and Divergence in Private International Law, p. 503.

124. Ibid.

125. Ibid.

126. Ibid. 
consumer's habitual residence, in spite of the existence of a cross-border element, the consumer conflicts rule shall not apply. ${ }^{127}$ The second approach is a broad interpretation approach, namely, Article 6(4)(a) Rome I Regulation is intended to protect the local service providers, a professional providing cross-border services does not deserve such protection, regardless of whether the services are supplied in the country of the consumer's habitual residence. ${ }^{128}$ Arguably, the second approach is more convincing, as the majority of tourism services are to be provided in a foreign country other than that of the consumer's habitual residence. Yet the reasonable expectation of the business party should be protected under the conditions set out in Articles 6(1)(a)-(b) Rome I Regulation. $^{129}$

4. Any other tourist service not intrinsically part of a travel service. The fourth type of travel service enshrined in Article 3(1)(d) Directive 2015/2302 covers 'any other tourist service not intrinsically part of a travel service within the meaning of points (a), (b) or (c)'. These tourist services may be admission to concerts, sport events, excursions or event parks, guided tours, ski passes and rental of sports equipment such as skiing equipment or spa treatments. ${ }^{130}$

(I) 'Not intrinsically part of. As to what does it mean 'not intrinsically part of' or 'tourist services which are not intrinsically part of', Directive 2015/2302 also gives an explanation with specific examples. First, tourist services that are intrinsically part of a travel service, for instance financial services such as travel insurances, should not be considered as travel services. ${ }^{131}$ In addition, services which are intrinsically part of another travel service, for instance transport of luggage provided as part of carriage of passengers, minor transport services such as carriage of passengers as part of a guided tour or transfers between a hotel and an airport or a railway station, meals, drinks and cleaning provided as part of accommodation, or access to on-site facilities such as a swimming pool, sauna, spa or gym included for hotel guests, should not be considered as independent travel services. ${ }^{132}$ As mentioned above, unlike in the case of a cruise, overnight accommodation provided as part of passenger transport by road, rail, water or air, accommodation should not be considered as a travel service in its own right if the main component is clearly transport. ${ }^{133}$

(II) 'A significant proportion'. Moreover, in order to constitute an independent component of a package travel, two more requirements must be met. The first requirement is that such tourist services must account for a significant proportion of the value of the combination or are advertised as and represent an essential feature of the combination. ${ }^{134}$ As to the meaning of 'a significant proportion', pursuant to Recital 18 of Directive 2015/2302, if a tourist service accounts for $25 \%$ or more of the value of the combination, such tourist service should be considered as representing a significant proportion of the value of the package. The second requirement is that such tourist services are not selected and purchased only after the performance of a travel service, such as carriage of passengers, accommodation or rental of cars, has started. ${ }^{135}$ For instance, if such tourist service is added, for

127. Ibid., p. 504.

128. Ibid.

129. L. Gillies, 60 ICLQ (2011), p. 560.

130. Recital 18 of Directive 2015/2302.

131. Recital 17 of Directive 2015/2302.

132. Ibid.

133. Ibid

134. Article 3(2)(a) and Recital 18 of Directive 2015/2302.

135. Article 3(2)(b) and Recital 18 of Directive 2015/2302. 
instance, to hotel accommodation which was booked as a stand-alone service, after the traveller's arrival at the hotel, this should not constitute a package. ${ }^{136}$ Notwithstanding this, if organizers or retailers offer the traveller the selection of additional tourist services in advance and then conclude a contract for those services only after the performance of the first travel service has started, this practice clearly aims to circumvent Directive 2015/2302 and should not be upheld. ${ }^{137}$

(III) Interaction between Article 17(3) Brussels Ibis Regulation and Article 3(I)(d) Directive 20I5/ 2302. It is questionable whether the term 'travel' stipulated in Article 17(3) Brussels Ibis Regulation can be interpreted exactly as the notion 'any other tourist service not intrinsically part of a travel service within the meaning of points (a), (b) or (c)' enshrined in Article 3(1)(d) Directive 2015/2302. The CJEU's judgment in Pammer case would indicate that it is of relevance to interpret the term 'travel' in Article 17(3) Brussels Ibis in line with Article 3(1)(d) Directive 2015/ 2302, but it does not mean these two terms are to be construed precisely as the same meaning. As a matter of fact, the 'transport+' package covered in Article 17(3) Brussels Ibis is narrower than that in Article 6(4)(b) Rome I, as discussed above. Such gap is widened because of the extended notion of package in Directive 2015/2302 and the lack of direct interaction between Article 17(3) Brussels Ibis Regulation and Directive 2015/2302.

5. Linked travel arrangements. Directive 2015/2302 includes two forms of travel arrangements, that is, 'package travel contract' ${ }^{138}$ and 'linked travel arrangement'. ${ }^{139}$ A linked travel arrangement (LTA) also comprises two types of travel services purchased for the purposes of the same trip or holiday, but it does not constitute a package travel. ${ }^{140}$ Despite the fact that the majority of travellers buying packages or LTAs are consumers within the meaning of EU consumer law, ${ }^{141}$ protective consumer jurisdiction and choice-of-law rules in Brussels Ibis Regulation and Rome I Regulation merely apply to package travel contracts, not to LTAs. The question is how to distinguish a package travel contract from a LTA.

The definition of package travel is split by Directive 2015/2302 into a range of elements that overlap and, in a broad sense, interacts with LTAs, ${ }^{142}$ considering both include separate contracts, ${ }^{143}$ individual travel service providers, ${ }^{144}$ a single point of sale, and a combination of single travel services. ${ }^{145}$ The difference is, first, LTAs are concluded only as separate contracts, whereas package travel contracts can be concluded as both a single contract and separate contracts. ${ }^{146}$ The combined travel services in a package travel are advertised or sold under the term 'package ${ }^{147}$ or under a similar term indicating a close connection between the travel services, such as 'combined deal', 'all-inclusive' or 'all-in arrangement'. ${ }^{148}$ Such an advertising of a

136. Recital 18 of Directive 2015/2302.

137. Ibid.

138. Article 3(3) of Directive 2015/2302.

139. Article 3(5) of Directive 2015/2302.

140. M.G. Sanches Lima, Traveller Vulnerability in the Context of Travel and Tourism Contracts, p. 136.

141. Recital 7 of Directive 2015/2302.

142. M.G. Sanches Lima, Traveller Vulnerability in the Context of Travel and Tourism Contracts, p. 137.

143. Directive 2015/2302, Article 3(2)(b) for Package, and Article 3(5) for LTA.

144. Ibid.

145. Directive 2015/2302, Article 3(2)(b) for Package, and Article 3(5)(a) for LTA.

146. M.G. Sanches Lima, Traveller Vulnerability in the Context of Travel and Tourism Contracts, p. 137.

147. Directive 2015/2302, Article 3(2)(b)(iii).

148. Ibid., Recital 10. 
package deal often results in the conclusion of a single contract. In a package travel, the travel services selected by the traveller are offered, sold or charged at an inclusive or total price. ${ }^{149}$ By contrast, in a LTA, it is a system of separate selection and separate payment. ${ }^{150}$

Second, the travel services in a package travel are combined by one trader, including at the request of or in accordance with the selection of the traveller, ${ }^{151}$ only one trader is involved as the main actor. The main characteristic of a package is that there is one trader responsible as an organizer for the proper performance of the package as a whole, and it should make no difference whether that trader is acting on the supply side or presents himself as an agent acting for the traveller. ${ }^{152}$ By contrast, a combination of travel services in LTAs is the result of a trader facilitating, on the occasion of a single visit or contact with his point of sale, the separate selection and separate payment ${ }^{153}$ of each travel service by travellers; ${ }^{154}$ or 'in a targeted manner, the procurement of at least one additional travel service from another trader where a contract with such other trader is concluded at least 24 hours after the confirmation of the booking of the first travel service'. ${ }^{155}$ Accordingly, there are at least two traders involved in a LTAs, and one trader acts as a facilitator of another trader.

Third, the purchasing method through an online linked booking processes does not constitute a special feature for a package travel nor for a LTA. ${ }^{156}$ Nevertheless, online LTAs should be distinguished from linked websites which do not have the objective of concluding a contract with the traveller. ${ }^{157}$ Such linked websites simply informed travellers about further travel services in a general way, for instance, a website of a hotel or an organizer of an event includes a list of all operators offering transport services to its location independently of any booking or if 'cookies' or metadata are used to place advertisements. ${ }^{158}$

Fourth, although a LTA does not constitute a package travel, travel services purchased from separate traders through linked online booking processes (LOBP) might qualify as a package travel, if the traveller's name, payment details and email address are transmitted from the trader with whom the first contract is concluded to another trader and a contract with the latter trader is concluded at the latest 24 hours after the confirmation of the booking of the first travel service. ${ }^{159}$ Interestingly, in the same situation, if the traveller's personal information is not transmitted from one trader to another trader through LOBP, the combined travel services constitute LTAs. ${ }^{160}$ The LOBP, in essence, is a

149. Ibid., Article 3(2)(b)(ii).

150. Ibid., Article 3(5)(a). For instance, an airline company which does not commit itself to provide accommodation services to its passengers merely provides information of certain hotels at its website by including a hyperlink to these hotels. If a consumer, after booking the flight, clicks on the hyperlink and makes a hotel reservation, a contract of accommodation is concluded between the consumer and the hotel owner. R. Steennot, Booking Your Holiday Online: Which Law Applies?, https://biblio.ugent.be/publication/5749826/file/5749863.pdf, p. 2.

151. Ibid., Article 3(2)(a).

152. Ibid., Recital 22.

153. For instance, an airline sells a flight ticket on its website, after concluding the contract with a traveller, presents an option to select a hotel with which the traveller can directly enters into a contract. CB, The European Package Travel Directive, www.cbi.eu/market-information/tourism/how-work-new-2018-european-package-travel-directive.

154. Directive 2015/2302, Article 3(5)(a).

155. Directive 2015/2302, Article 3(5)(b).

156. Ibid., Recital 9.

157. Ibid., Recital 12.

158. Ibid., Recital 12.

159. Ibid., Article 3(2)(b)(v).

160. Ibid., Article 3(5)(b). 
way businesses operationalize the purchasing of travel services, the purpose of which is to facilitate the procurement of at least one additional travel service from another trader within 24 hours after the first booking. ${ }^{161}$ A combined travel services through LOBP can be: (i) a subset of package travel under Article 3(2)(v), if the traveller's personal data are transferred between traders in the click-through booking; or (ii) a subset of linked travel arrangement under Article $3(5)(b)$, if the traveller's personal data are not automatically transferred from one trader to another trader. ${ }^{162}$

A combined travel services purchased via LOBP, be it as a subset of package travel or linked travel arrangements, represent the travel businesses' intention to cooperate and work together on their mutual interests. ${ }^{163}$ Conversely, combined travel services purchased independently by travellers via linked websites are neither a package travel nor a LTA, as the linked websites only provide advertisement and information on travel services in a general way, such as a list of transport services, without the objective of concluding a contract with the traveller. $^{164}$

In conclusion, the packages covered by Directive 2015/2302 include customized or tailormade packages, online contracts, dynamic packages, as well as services purchased from separate traders via associated linked online booking processes (affiliates or dynamic click-through packages). ${ }^{165}$ Apparently, the packages included in Article 17(3) Brussels Ibis Regulation and Article 6(4)(b) Rome I Regulation are limited to 'transport+' combinations and thus are narrower than that in Directive 2015/2302. There is no reason not including other types of packages into the protective consumer jurisdiction and applicable law rules. A package travel tourist should be protected as a consumer in the field of private international law, irrespective of whether that package contains transport component or not. To this end, it is more logical to remove packages from the scope of the exception for transport contracts and add a separate provision, in parallel with Article 17(3) Brussels Ibis and Article 6(4)(b) Rome I, to protect all package travel contracts as consumer contracts. In this regard, the framework in Article 5 Rome Convention is worthy of reference. According to Article 5(4)(a) Rome Convention, carriage contracts were excluded from the consumer choice-of-law rules, whereas Article 5(5) included package travel contracts to the material scope of protective consumer conflicts rules.

\section{Conclusion}

The relationship between the Brussels Ibis Regulation and the Rome I Regulation is like a tango couple dancing in the dance pool of private international law. In terms of consumer protection in package travel contracts, when the background music has changed from Directive 90/314 to Directive 2015/2302, it is crucial for these two Regulations to change their steps accordingly in order to keep up with the change. The reality is that when Article 6(4)(b) Rome I Regulation is dancing under the beat of the Directive 2015/2302, Article 17(3) Brussels Ibis Regulation is still

161. M.G. Sanches Lima, Traveller Vulnerability in the Context of Travel and Tourism Contracts, p. 138.

162. Ibid.

163. Ibid.

164. Ibid.

165. F. Morandi, 'The New Italian Regulation on Package Travel and Linked Travel Arrangements According to Directive (EU) 2015/2302', 3 European Common Market Law Review (2020), p. 94. 
dancing under the beat of Article 5(5) 1980 Rome Convention, the predecessor of Article 6(4)(b) Rome I. Unlike Article 6(4)(b) Rome I, there is no direct interaction between Article 17(3) Brussels Ibis and Directive 2015/2302 via its Article 29. As a result, in terms of consumer protection for package travel tourists, Article 17(3) Brussels Ibis has been two steps behind Article 6(4)(b) Rome I.

Despite this, it is never too late to take actions or to change steps. When your footsteps are wrong in tango, the best strategy is changing your steps as quick as possible to keep pace with your dancing partner. Therefore, it is crucial for Brussels Ibis Regulation to adjust its next step by referring to the concept of package travel laid down in Directive 2015/2302. Having regard to the wording employed in Article 6(4)(b) Rome I Regulation, a possible proposal for revising Article 17(3) Brussels Ibis Regulation in the future would be as follows:

This Section shall not apply to a contract of transport other than a contract relating to package travel within the meaning of Council Directive 2015/2302/EU of 25 November 2015 on package travel and linked travel arrangements.

Even if Article 17(3) Brussels Ibis adopts the same package definition as Article 6(4)(b) Rome I, such packages, as an exception of transport contracts, are limited to those including transport. Yet package travel contracts, regardless of containing transport or not, should be protected as consumer contracts under Articles 17-19 Brussels Ibis and Article 6 Rome I. In order to provide a consistent interpretation of 'Europeanized' conflicts rules and meanwhile observe developments towards the maximization of consumer protection, ${ }^{166}$ it is more logical to delete the exception for transport contracts and establish a new provision, in parallel with Article 17(3) Brussels Ibis and Article 6(4)(b) Rome I, to regulate package travel contracts. As a result, Article 17(3) Brussels Ibis and Article 6(4)(b) Rome I can be simplified as 'This Section/article shall not apply to a contract of transport/carriage', whereas package travel contracts are expressly regulated as consumer contracts in a separate provision. In this regard, the framework in Article 5 Rome Convention is a better solution, according to which package travel contracts can be expressly included in Article 17 Brussels Ibis/Article 6 Rome I as follows:

Notwithstanding Article 17(3) Brussels Ibis/Article 6(4)(b) Rome I, this Section/article shall apply to a contract relating to package travel within the meaning of Council Directive 2015/2302/EU of 25

November 2015 on package travel and linked travel arrangements.

\section{Acknowledgements}

I would like to deliver thanks to my supervisor Professor Mathijs H. Ten Wolde and Kirsten C. Henckel for their useful comments to revise the original manuscript. In addition, the reviewers have provided thoughtful comments to further improve this article, many thanks.

\section{Declaration of Conflicting Interests}

The author declared no potential conflicts of interest with respect to the research, authorship, and/or publication of this article.

166. L. Gillies, 60 ICLQ (2011), p. 563. 


\section{Funding}

The author disclosed receipt of the following financial support for the research, authorship, and/or publication of this article: This work was supported by the China Scholarship Council

\section{ORCID iD}

Zhen Chen (D) https://orcid.org/0000-0001-5323-4271 